\title{
Special Announcements
}




\title{
Special Announcements
}

\author{
American Committee to promote Studies \\ of the History of the Habsburg Monarchy
}

At the annual business meeting of the Conference Group for Central European History in Los Angeles, California, on December 29, 1981, George Barany, of the University of Denver, was elected to replace Klemens von Klemperer, of Smith College, as executive secretary of the American Committee to promote Studies of the History of the Habsburg Monarchy. Barbara Jelavich, of Indiana University, was elected to replace him as a member of the committee. At the business meeting in Washington, D.C., on December 29, 1982, Paul Schroeder, of the University of Illinois at Urbana, was elected to replace Peter F. Sugar, of the University of Washington, as a member of the committee. The committee is now composed of the following members: George Barany, of the University of Denver (executive secretary); Barbara Jelavich, of Indiana University; William J. McGrath, of the University of Rochester; Stanley Z. Pech, of the University of British Columbia; Paul Schroeder, of the University of Illinois at Urbana; Andrew G. Whiteside, of Queens College of the City University of New York; and William E. Wright, of the University of Minnesota (ex officio member).

\section{Conference Group for Central European History}

The general business meeting of the Conference Group for Central European History, which took place in Los Angeles, California, on December 29, 1981, was chaired by Peter Paret, of Stanford University. Gerhard L. Weinberg, of the University of North Carolina, followed him as chairman for 1982. Klemens von Klemperer, of Smith College, was elected vicechairman and Geoffrey H. Eley, of the University of Michigan at Ann Arbor, was elected to a two-year term on the executive board. At the annual business meeting in 1982 Klemens von Klemperer succeeded Gerhard L. Weinberg as chairman. Annaliese Thimme, of the University of Alberta, was elected vice-chairman, and Konrad Jarausch, then at the University of Missouri, secretary-treasurer. Steven Rowan, of the University of Missouri at St. Louis, and Robert Wolf, of the National Archive and Research Services, were elected members of the executive board.

American Association for the Study of Hungarian History

At the business meeting in Los Angeles, California, on December 29, 
1981, Steven Béla Vardy, of Duquesne University, succeeded Béla K. Király, of Brooklyn College of the City University of New York, as chairman for the years 1982-1983. Joseph Held, of Rutgers University, was elected to a two-year term as vice-president, while Edsel Walter Stroup was reelected as secretary-treasurer. Also at the Los Angeles meeting Lee Congdon, László Deme, Bennett Kovrig, and Peter Pastor were elected members of the executive board for two-year terms. At the business meeting in Washington, D. C., in December, 1982, L. S. Domonkos and Linda Frey were elected to memberships on the committee for two-year terms.

\section{Center for Austrian Studies University of Minnesota}

Austria since 1945, published papers of the first annual symposium of the Center (1978), edited by William E. Wright, is now available from the Center for $\$ 5.00$ plus $\$ 1.00$ for handling and mailing (Minnesota residents must add $6 \%$ for sales tax).

The next annual spring symposium, cosponsored by the Center and the School of Journalism and Mass Communications, will have as its theme, "Austria and the United States in the World of Mass Communications", and will take place on the University of Minnesota campus on 17, 18 and 19 May 1984. Speakers will be drawn from the world of publishing, academia, communications, and the respective governments. Those interested in participating or attending should please write to Professor William E. Wright, Director, Center for Austrian Studies, 712 Social Sciences Building, 267 19th Ave. S., University of Minnesota, Minneapolis, Minn. 55455, or call (612) 373-4670.

The Center for Austrian Studies has been exceedingly fortunate in acquiring the library of the late Professor Robert A. Kann. Mrs. Marie Kann very kindly agreed that the University of Minnesota Libraries might establish the Robert A. Kann Memorial Collection in the Special Collections Division of O. M. Wilson Library. The Collection will be dedicated and a Robert A. Kann Memorial Lecture will be given by Professor emeritus Carl Schorske on April 19, 1984. 